\title{
PENGARUH PERAN MASYARAKAT MADANI DAN SISTEM PENGENDALIAN INTERN TERHADAP OPINI AUDIT LAPORAN KEUANGAN PEMERINTAH DAERAH (STUDI PADA KABUPATEN/KOTA DI PROVINSI ACEH)
}

\author{
Juanda Surya*1, Suparno ${ }^{* 2}$ \\ ${ }^{1,2}$ Program Studi Akuntansi Fakultas Ekonomi dan Bisnis Universitas Syiah Kuala \\ e-mail: Juandasurya95@gmail.com ${ }^{* 1}$, suparno.feusk@gmail.com ${ }^{* 2}$
}

\begin{abstract}
The purpose of this study is to examine the influence of civil society roles proxyed by human development index variables, community education level, and income level of the community, and internal control system to audit opinion of local government financial report on districts / cities in Aceh Province. The method used in this research is census method. The data used are secondary data in the form of human development index data, income level of society, level of public education and report of examination result of Supreme Audit Board of Republic Indonesia. Objects in this study are all districts/cities in Aceh Province which consists of 18 districts and 5 cities. The analysis used is logistic regression analysis. The results of this study indicate that (1) the human development index influence on the audit opinion of the local government financial report (2) the education level of the community influences on the audit opinion of the local government financial report (3) the income level of society influences on the audit opinion of local government financial report (4) The internal control system influence on the audit opinion of local government financial report.
\end{abstract}

Keywords: civil society, human development index, community education level, income level of society, and internal control system.

\section{Pendahuluan}

Akuntabel dan transparan merupakan pilar yang menopang tata kelola keuangan yang baik sehingga tercipta kemakmuran rakyat. Stewart dalam teorinya Stewart's Ladder of Accountability mengemukakan bahwa untuk menjadi akuntabel perlu melewati langkah-langkah salah satunya yaitu probity dan legality (Akbar, 2015). Pada era otonomi daerah saat ini, dalam rangka pengelolaan keuangan daerah laporan pertanggungjawaban menjadi salah satu faktor yang krusial, kemudian laporan pertanggungjawaban keuangan pemerintah akan dinilai kewajaran, keandalan, kecermatan, dan kredibelitas informasinya oleh Badan Pemeriksa Keuangan (BPK) dengan melakukan pemeriksaan yang hasilnya dituangkan dalam bentuk laporan hasil pemeriksaan atas laporan keuangan pemerintah yang memuat opini tentang tingkat kewajaran informasi yang disajikan dalam laporan keuangan pemerintah (UU Nomor 15 Tahun 2004 pasal 16).

Opini audit pemerintah daerah merupakan salah satu parameter penilaian akuntabilitas pemerintahan di daerah. Disisi lain daerah yang memperoleh opini Wajar Tanpa Pengecualian (WTP) pada Ikhtisar Hasil Pemeriksaan BPK pada 2010, 2011, 2012, 2013, 2014 dan 2015 atas Laporan Keuangan Pemerintah Daerah (LKPD) masih berjumlah sedikit. LKPD merupakan laporan keuangan yang keandalannya harus dapat dipertanggungjawabkan. Sejak diberlakukanya otonomi daerah, dana yang dikelola oleh pemerintah daerah dan wewenang yang diberikan kepada daerah semakin besar. Pemerintah daerah harus berusaha keras untuk memperoleh opini WTP karena pada dasarnya Opini WTP hanya diberikan untuk LKPD yang disajikan secara wajar dalam semua hal yang material, sesuai dengan prinsip akuntansi yang berlaku umum di Indonesia (Undang-Undang Nomor 15 Tahun 2004), ini artinya opini WTP melekat pada laporan keuangan yang dapat diandalkan sebagai dasar dalam pengambilan keputusan. Salah satu target Rencana Pemerintah Jangka Menengah Nasional (RPJMN) Tahun 2010-2014 yaitu provinsi dan kabupaten/kota memiliki LKPD beropini WTP, dengan persentase $15 \%$ untuk tahun $2010,30 \%$ untuk tahun $2011,50 \%$ 
untuk tahun 2012, 75\% untuk tahun 2013 dan 100\% untuk tahun 2014.

Faktor-faktor yang mempengaruhi pemberian opini audit oleh BPK harus diperhatikan oleh masingmasing daerah khususnya kepala daerah. Kepala daerah merupakan pemegang kekuasaan eksekutif yang dipercaya oleh rakyat untuk menjalankan pemerintahan di suatu daerah. Pertimbangan auditor terhadap kelemahan sistem pengendalian intern merupakan faktor yang mempengaruhi perolehan opini WTP oleh pemeritah daerah yang didukung oleh beberapa penelitian, Kawedar (2009), Fatimah, Sari, dan Rasuli (2014), Safitri (2015), serta Munawar, Nadirsyah, dan Abdullah (2016). Hasil penelitian tersebut secara umum menemukan bahwa kelemahan sistem pengendalian intern dalam penyajian laporan keuangan menyebabkan penurunan opini audit pada laporan keuangan pemerintah daerah. Keterlibatan warga negara dapat memperkuat lembaga-lembaga pengawasan independen untuk menahan pejabat publik bertanggungjawab atas penggunaan sumber daya publik yang pada dasarnya terbatas dan untuk kinerja untuk tujuan yang jelas (UN, DESA 2013). Analisis status interaksi Supreme Audit Institutions (SAI)warga berupa Communication between SAIs and citizens, Citizen participation in government auditing, SAIs, parliaments and citizens.

Peran masyarakat madani merupakan salah satu kunci utama terciptanya good governance. Menurut Adzani dan Martani (2014), masyarakat madani mencerminkan suatu masyarakat yang sejahtera dan berkeadilan, beberapa parameter masyarakat madani adalah tingkat pembangunan manusai, tingkat pengetahuan masyarakat, tingkat harapan hidup, dan tingkat kesejahteraan, penelitian ini menemukan bahwa masyarakat madani memiliki pengaruh positif yang signifikan terhadap opini audit maupun peningkatan opini audit. Variabel yang berpengaruh tersebut adalah tingkat pembangunan manusia, tingkat pendidikan, dan tingkat pendapatan. Penelitian yang dilakukan oleh Wambui dan Kihonge (2016) menemukan bahwa kesadaran masyarakat madani memiliki pengaruh yang signifikan dalam partisipasi masyarakat dalam manajemen keuangan pemerintah daerah. Kurangnya pemahaman tentang anggaran dan prosedur penganggaran partisipasi membuat warga kurang terlibat di bidang keuangan publik. Penelitian yang dilakukan oleh Albert, Bawole dan Domfeh (2013), yang menemukan hanya sedikit ruang yang ada untuk para pemangku kepentingan, ini dikarenakan kurangnya pemahaman yang tepat dari perencanaan, penganggaran dan sistem pengelolaan keuangan kabupaten assemblie. Hal ini menunjukkan bahwa peran masyarakat tidak dapat dihindarkan dari pemerintahan itu sendiri karena semakin baik peran masyarakat maka tata kelola pemerintahan yang ditinjau dari sisi akuntabilitas keuangan semakin baik karena tujuan audit itu sendiri untuk meningkatkan akuntabilitas dalam keuangan publik sehingga terciptanya efektivitas dan efisiensi.

\section{Landasan Teori dan Pengembangan Hipotesis Landasan Teori \\ Good Governance}

World bank mendefenisikan good governance sebagai sebagai tata kelola yang terbuka, proses kebijakan yang transparan, birokrasi yang dipenuhi dengan etos profesional, pemerintah yang bertanggung jawab atas tindakannya, masyarakat yang ikut berpartisipasi dalam urusan publik dan semua berperilaku di bawah aturan hukum. Menurut Susanto, Yusuf, dan Rachmawati (2014), Good Governance bertujuan untuk menyelaraskan tujuan atau kepentingan antara pemegang saham (principal) dan manajemen (agen) perusahaan sehingga dapat meminimalkan konflik keagenan diantara mereka serta good governance juga dapat mengurangi praktekpraktek bisnis yang tidak sehat, sedangkan pada sektor publik penerapan good governance bertujuan untuk meningkatkan kesejahteraan masyarakat, menciptakan iklim bisnis yang sehat, meningkatkan iklim daya saing, serta dapat mencegah terhadap tindakan korupsi.

\section{Agency Theory}

Teori keagenan menjelaskan adanya hubungan antara pemilik (principal) dengan manajemen (agent) (Jensen and Meckeling, 1976). Adanya pemisahan kepemilikan oleh principal dengan pengendalian oleh agent dalam sebuah organisasi cenderung menimbulkan konflik keagenan di antara kedua pihak tersebut. Agent bertindak opportunis guna memaksimalkan kepentinganya sendiri, hasil penjarahan uang rakyat melalui proyek-proyek fiktif, proyek penuh mark-up, dinikmati oleh pejabat (agent) dan kroni-kroninya. Kondisi seperti ini disebabkan karena terjadi asymetry information yang didukung 
oleh praktek KKN (korupsi, kolusi, dan nepotisme) dan kurangnya pengawasan dari masyarakat selaku Principal (Ulum, 2011). Menurut Ratmono (2015), masyarakat selaku principal memberikan amanat kepada pemda, pemda selaku agent memiliki kewajiban untuk melaporkan hasil pelaksanaan pemerintahan kepada masyarakat yaitu hasil pelaksanaan pemerintahan terkait dengan penggunaan sumber daya yang telah dipercayakan masyarakat selaku principal dalam bentuk laporan keuangan.

\section{Pengembangan Hipotesis \\ Indeks Pembagunan Manusia}

Tingkat pembangunan masyarakat menunjukkan tingkat kemajuan yang dicapai suatu masyarakat. Tingkat pembangunan masyarakat dapat diukur salah satunya melalui IPM. Tata kelola pemerintahan yang baik mensyaratkan adanya keberadaan masyarakat yang tingkat pembangunannya baik pula (Ramachandran 2002). Penelitian yang dilakukan Justus (2016), menunjukkan bahwa adanya hubungan yang positif dan signifikan antara indeks pembangunan manusia dan tata kelola pemerintahan yang baik. Berdasarkan penjelasan di atas dapat dikatakan bahwa indeks pembangunan manusia berpengaruh terhadap good government governance dan juga opini audit laporan keuangan pemerintah.

$\mathrm{H}_{1}$ : Indeks pembangunan manusia berpengaruh terhadap opini audit laporan keuangan pemerintah daerah pada kabupaten/kota di Provinsi Aceh.

\section{Tingkat Pendidikan Masyarakat}

Pengalokasian anggaran pemerintah untuk sektor pendidikan merupakan komponen terpenting dalam kebijakan anggaran untuk peningkatan kecerdasan bangsa. Menurut Lurie (2014), negara dengan masyarakat yang lebih terdidik secara konsisten memiliki pemerintahan yang lebih baik, pada sejumlah penilaian. Beberapa perbandingan yang dibuat pendidikan dibandingkan dengan Indikator Governance Bank Dunia dan Indeks Persepsi Korupsi International. Menurut Knack (2002), warga yang berpendidikan yang lebih baik mungkin lebih efektif dalam menuntut pemerintahan yang lebih efisien dan juga bisa menyediakan angkatan kerja yang lebih baik ketika pemerintah membutuhkan tenaga kerja yang handal. Penelitian yang dilakukan Kadagidze (2015) menunjukkan bahwa pendidikan merupakan bagian dari transFormasi masyarakat madani dimana warga negara yang memiliki latar beakang akademis berpartisipasi aktif dalam urusan publik.

$\mathrm{H}_{2}$ : Tingkat pendidikan masyarakat berpengaruh terhadap opini audit laporan keuangan pemerintah daerah Pada kabupaten/kota di Provinsi Aceh.

\section{Tingkat Pendapatan Masyarakat}

Tingkat kesejahteraan dapat diukur dari pendapatan per kapita masyarakat. Menurut Knack (2002), warga berpenghasilan tinggi dengan pendidikan yang lebih baik mungkin lebih efektif dalam menuntut pemerintahan yang lebih efisien sedangkan dari sisi lain warga dengan pendidikan dan pendapatan yang lebih baik akan berkontribusi pada penerimaan pajak pemerintah yang lebih besar. Kemudian menurut Ott (2010), orang-orang bahagia memiliki keinginan tinggi untuk memilih, melakukan lebih banyak pekerjaan relawan, dan lebih sering berpartisipasi dalam kegiatan publik dimana variabel control dalam penelitianya menggunakan tingkat pendapatan.

Level ekonomi dalam masyarakat daerah dapat mempengaruhi pengungkapan informasi keuangan oleh pemerintah daerah. Pendapatan per kapita berpengaruh terhadap pelaporan keuangan di internet oleh pemerintah daerah di Indonesia (Mahmud dan Hudoyo, 2014). Perekonomian masyarakat setempat juga mempengaruhi pendapatan perkapita masyarakat. Perekonomian masyarakat setempat juga mempengaruhi teknologi yang di adaptasi oleh masyarakat tersebut. Sehingga, pengungkapan laporan keuangan di internet pun bisa menjadi terpengaruh oleh pendapatan perkapita daerah tersebut.

$\mathrm{H}_{3}$ : Tingkat pendapatan masyarakat berpengaruh terhadap opini audit laporan keuangan pemerintah daerah Pada kabupaten/kota di Provinsi Aceh.

\section{Sistem Pengendalian Intern}

Bagi auditor selaku pemberi opini, menjadikan sistem pengendalian intern sebagai informasi penting dalam perencanaan uji tertentu untuk menentukan kecenderungan dan keluasan kesalahan penyajian laporan keuangan (Hall and Tommie, 2007: 41). Pertimbangan auditor terhadap kelemahan sistem 
pengendalian intern dalam pemberian opini telah dibuktikan dari beberapa penelitian yang dilakukan oleh Kawedar (2009), Fatimah, Ria, dan Rasuli (2014), Safitri (2015), serta Munawar, Nadirsyah dan Abdullah (2016). Hasil penelitian tersebut secara umum menyimpulkan kelemahan sistem pengendalian intern dalam menyajikan laporan keuangan menyebabkan penurunan opini atau diperolehnya opini berupa opini wajar dengan pengecualian, disclaimer bahkan opini tidak wajar.

$\mathrm{H}_{4}$ : Pengendalian intern berpengaruh terhadap opini audit laporan keuangan pemerintah daerah Pada kabupaten/kota di Provinsi Aceh.

\section{Metode Penelitian}

\section{Populasi dan Sampel}

Populasi dalam penelitian ini yaitu seluruh Kabupaten /Kota di Provonsi Aceh dari 23 kabupaten/kota yang terdiri dari 18 kabupaten dan 5 kota yang akan diamati selama 6 tahun dari tahun 2010-2015. Teknik sampling yang digunakan dalam penelitian ini adalah teknik sampling jenuh atau metode sensus.

\section{Jenis dan Sumber Data}

Metode pengumpulan data pada penelitian ini menggunakan data sekunder, yaitu informasi yang diperoleh dari pihak lain (Sekaran dan Bougie, 2013). Penelitian ini menggunakan data sekunder untuk menganalisis dan menguji hipotesis. Hal ini dilakukan karena data tersebut sudah tersedia berupa indeks pembangunan manusia, data jumlah penduduk, PDRB, rata-rata lama sekolah dan dokumen LHP atas pengendalian intern BPK RI untuk semua Kabupaten/Kota di Aceh tahun 2010-2015.

\section{Model Penelitian}

Metode analisis yang digunakan dalam penelitian ini adalah metode analisis regresi logistik (logistik regression). Pengujian hipotesis dilakukan menggunakan analisis regresi logistik karena variabel dependen diuji dengan variabel dummy (Ghozali, 2013:178).

$$
Y=\alpha+\beta_{1} X_{1}+\beta_{2} X_{2}+\beta_{3} X_{3}-\beta_{4} X_{4}+\varepsilon
$$

dimana:

$\alpha=$ Nilai konstanta

$\beta=$ Nilai Koefisien regresi variabel

$\mathrm{X}_{1}=$ Indeks Pembangunan Manusia

$\mathrm{X}_{2}=$ Tingkat Pendidikan

$\mathrm{X}_{3}=$ Tingkat Pendapatan

$\mathrm{X}_{4}=$ Sistem pengendalian Intern

$\varepsilon=$ eror

\section{Pengukuran Variabel}

Tabel 3.1

Operasionalisasi Variabel

\begin{tabular}{|l|l|l|l|}
\hline No & \multicolumn{1}{|c|}{ Variabel } & Rumus regresi & \multicolumn{1}{c|}{ Perhitungan } \\
\hline 1 & Opini Audit & Audit_Op & $\begin{array}{l}\text { Variabel dummy, dimana 1 untuk perusahaan yang menerima opini } \\
\text { wajar tanpa pengecualian, dan 0 untuk perusahaan yang menerima } \\
\text { opini selain wajar tanpa pengecualian atau } \text { non-WTP. }\end{array}$ \\
\hline 2 & $\begin{array}{l}\text { Indeks Pembangunan } \\
\text { Manusia }\end{array}$ & Intern_c & $\begin{array}{l}\text { Pembangunan manusia adalah proses yang meningkatkan aspek } \\
\text { kehidupan masyarakat, data yg digunakan dilihat dari nilai indeks } \\
\text { pembangunan manusia Kabupaten/kota di provinsi Aceh }\end{array}$ \\
\hline 3 & $\begin{array}{l}\text { Tingkat Pendidikan } \\
\text { masyarakat }\end{array}$ & IPM & $\begin{array}{l}\text { Tingkat pendidikan akan diukur dengan rata-rata lama sekolah dari } \\
\text { penduduk suatu Pemda. Sumber data adalah hasil Survey Sosial } \\
\text { Ekonomi Nasional dari Biro Pusat Statistik Republik Indonesia }\end{array}$ \\
\hline 4 & $\begin{array}{l}\text { Tingkat Pendapatan } \\
\text { Masyarakat }\end{array}$ & Educ & \multicolumn{1}{c|}{$\begin{array}{l}\text { PDRB tahun t } \\
\text { Penduduk daerah dalam tahunt }\end{array}$} \\
\hline 5 & $\begin{array}{l}\text { Sistem Pengendalian } \\
\text { Intern }\end{array}$ & Earnings & $\begin{array}{l}\text { Kelemahan SPI sebagai salah satu variabel bebas dalam penelitian } \\
\text { ini diukur dengan jumlah temuan di masing-masing tahun } \\
\text { pemeriksaan terkait kelemahan SPI yang diperoleh dari Laporan } \\
\text { Hasil Pemeriksaan BPK RI. }\end{array}$ \\
\hline
\end{tabular}




\section{Operasionalisasi Variabel}

\section{Variabel Terikat (Dependent Variable)}

Variabel terikat adalah variabel yang menjadi perhatian utama peneliti atau variabel yang menjadi faktor yang berlaku dalam investigasi (Sekaran dan Bougie, 2013:69). Variabel terikat dalam penelitian ini adalah opini audit atas laporan keuangan pemerintah daerah. Menurut Buletin Teknis SPKN Nomor 01, opini audit terdiri dari WTP (Wajar Tanpa Pengecualian) dan atau WTP DPP (Wajar Tanpa Pengecualian Dengan Paragraf Penelasan), WDP (Wajar Dengan Pengecualian), TW (Tidak Wajar), dan TMP (Tidak Memberikan Pendapat). Ukuran variabel dependen pada penelitian ini yaitu menggunakan variabel dummy berupa 1 dan $0, \mathrm{WTP}=1$ dan opini Non WTP $=0$.

\section{Variabel Bebas (Independent Variable)}

Variabel bebas adalah variabel yang secara positif atau negatif, dapat mempengaruhi variabel terikat. Dapat disimpulkan bahwa varians variabel terikat ditentukan oleh variabel bebas (Sekaran dan Bougie, 70:2013). Adapun variabel independen dalam penelitian ini yaitu:

\section{a. Indeks Pembangunan Manusia}

Pembangunan manusia adalah proses yang meningkatkan aspek kehidupan masyarakat, data yang digunakan dilihat dari nilai indeks pembangunan manusia Kabupaten/Kota di Provinsi Aceh.

\section{b. Tingkat pendidikan}

Penelitian ini akan menggunakan tingkat pendidikan masyarakat dalam suatu Pemerintah daerah untuk mengukur variabel tingkat pendidikan. Tingkat pendidikan akan diukur dengan rata-rata lama sekolah dari penduduk suatu pemerintah daerah. Sumber data adalah hasil survey sosial ekonomi nasional dari BPS Republik Indonesia .

\section{c. Tingkat pendapatan}

Pendapatan per kapita adalah besarnya pendapatan rata-rata penduduk di suatu daerah. Pendapatan per kapita didapat dari hasil pembagian pendapatan suatu daerah dengan jumlah penduduk daerah tersebut. Pendapatan per kapita juga menunjukkan Produk Domestik Regional Bruto (PDRB) per kapita. Cara penghitungan PDRB sebagai berikut:

\section{PDRB tahun $\mathrm{t}$ \\ $\overline{\text { Penduduk daerah dalam tahun } t}$}

\section{d. Sistem Pengendalian Intern}

SPI (Sistem Pengendalian Intern) sebagai salah satu variabel bebas dalam penelitian ini diukur dengan jumlah temuan di masing-masing tahun pemeriksaan terkait kelemahan SPI yang diperoleh dari Laporan Hasil Pemeriksaan BPK RI.

SPI = Jumlah Temuan atas Kelemahan SPI.

\section{Hasil dan Pembahasan Deskripsi Objek Penelitian}

Populasi dalam penelitian ini adalah seluruh kabupaten/kota di aceh yaitu sebanyak 18 kabupaten dan 5 kota. Periode waktu yang diteliti adalah selama tahun 2010-2015. Analisis data dilakukan dengan menggunakan metode regresi logistik dan pengujian hipotesis dilakukan sesuai dengan rancangan pengujian hipotesis yang telah dibuat. Data dalam penelitian ini diolah dengan menggunakan program IBM SPSS version 23 release 23.0 32-bit Edition.

Statistik deskriptif antara lain adalah penyajian data melalui tabel, grafik, diagram lingkaran, pictogram, perhitungan modus, median, mean (pengukuran tendensi sentral), perhitungan desil, persentil, perhitungan penyebaran data melalui perhitungan rata-rata dan standar deviasi, perhitungan persentase.

Tabel 4.1

Descriptive Statistics

\begin{tabular}{|l|r|r|r|r|r|}
\hline & \multicolumn{1}{|c|}{ N } & \multicolumn{1}{|c|}{ Minimum } & \multicolumn{1}{c|}{ Maximum } & \multicolumn{1}{c|}{ Mean } & \multicolumn{1}{c|}{ Std. Deviation } \\
\hline Audit_Op & 138 &, 00 & 1,00 &, 4130 &, 49417 \\
Intern_c & 138 & 2,00 & 29,00 & 10,6232 & 4,77249 \\
IPM & 138 & 58,97 & 83,25 & 67,1450 & 4,87832 \\
Educ & 138 & 5,59 & 12,38 & 8,4343 & 1,35888 \\
Earnings & 138 & 11,81 & 58,90 & 23,7925 & 10,17544 \\
Valid N (listwise) & 138 & & & & \\
\hline
\end{tabular}


Variabel dependen yaitu opini audit. Nilai terendah sebesar 0 artinya kabupaten/kota yang memperoleh opini wajar tanpa pengecualian dan nilai tertinggi 1 artinya kabupaten/kota yang memperoleh opini wajartanpa pengecualian. Nilai rata-rata sebesar 0,413 yang berarti bahwa nilai rata-rata opini audit laporan keuangan pemerintah daerah pada kabupaten/kota di Aceh sebesar 41\%, sedangkan standar deviasi sebesar 0,494.

Variabel independen yang pertama adalah indeks pembangunan manusia. Nilai terendah yang diperoleh sebesar 58,97 yaitu kabupaten Subulussalam dan nilai tertinggi yang diperoleh sebesar 83,25 yaitu kota Banda Aceh. Nilai rata-rata indeks pembangunan manusia adalah 67,145 dengan satandar deviasi 4,878.

Variabel independen yang kedua adalah tingkat pendidikan masyarakat. Nilai terendah yang diperoleh sebesar 5,59 yaitu kabupaten Gayo Lues dan nilai tertinggi yang diperoleh sebesar 12,38 yaitu kota Banda Aceh. Nilai tingkat pendidikan masyarakat adalah 8,434 dengan satandar deviasi 1,358.

Variabel independen yang ketiga adalah tingkat pendapatan masyarakat. Nilai terendah yang diperoleh sebesar 11,81 yaitu kabupaten Aceh Singkil dan nilai tertinggi yang diperoleh sebesar 58,90 yaitu kota Banda Aceh. Nilai rata-rata tingkat pendapatan masyarakat adalah 23,792 dengan satandar deviasi 10,175 .

Variabel yang keempat adalah sistem pengendalian intern. Nilai terendah yang diperoleh sebesar 2,00 yaitu kabupaten Aceh Tengah dan nilai tertinggi yang diperoleh sebesar 29,00 yaitu kabupaten Aceh Barat Daya. Nilai rata-rata sistem pengendalian intern adalah 10,623 dengan standar deviasi 4,772.

\section{Uji Penilaian Keseluruhan Model}

Pengujian ini dilakukan untuk menilai model yang telah dihipotesiskan telah fit dengan data. Hipotesis untuk menilai model fit adalah:

$\mathrm{H}_{0}$ : Model yang dihipotesiskan fit dengan data.

$\mathrm{H}_{1}$ : Model yang dihipotesiskan tidak fit dengan data.
Dari hasi pengujian diperoleh bahwa ketika variabel bebas yaitu indeks pembangunan manusia, tingkat pendidikan masyarakat, tingkat pendapatan masyarakat, dan sistem pengendalian intern dimasukkan ke dalam model -2LL menunjukkan angka 145,526 atau terjadi penurunan nilai -2LL sebesar 41,587. Penurunan nilai -2LL ini dapat diartikan bahwa penambahan variabel bebas kedalam model menunjukkan bahwa model regresi lebih baik atau dengan kata lain $\mathrm{H}_{0}$ diterima.

\section{Uji Kelayakan Model Regresi}

Pengujian kelayakan model regresi logistik dilakukan dengan menggunakan hosmer and lemeshow's goodness of fit test yang diukur dengan nilai Chi-Square. Model ini untuk menguji $\mathrm{H}_{0}$ bahwa data empiris sesuai dengan model. Jika nilai statistik Hosmer and Lemeshow Goodness of Fit Test $<0,05$ maka $\mathrm{H}_{0}$ ditolak. Hal ini berarti ada perbedaan yang signifikan antara model dengan nilai observasinya sehingga Goodness Fit modelnya tidak baik. sedangkan jika nilainya $>0,05$ maka $\mathrm{H}_{0}$ tidak dapat ditolak. Hasil pengujian hosmer and lemeshow's goodness of fit test menunjukkan, dengan probabilitas signifikan menunjukkan angka 0,220. Nilai signifikan yang diperoleh ini lebih besar dari 0,05 sehingga $\mathrm{H}_{0}$ diterima.

\section{Koefesien Determinasi}

Besarnya nilai koefisien determinasi pada model regresi logistik ditunjukkan dengan nilai Nagelkerke $R$ Square (R2), yaitu pengujian yang digunakan untuk mengukur seberapa jauh kemampuan variabel independen mampu menjelaskan dan mempengaruhi variabel dependen (Ghozali, 2013:97). Hasil pengujian menunjukkan nilai Nagelkerke $R$ Square sebesar 0,351 . Hal ini menunjukkan bahwa variabilitas variabel dependen dapat dijelaskan oleh variabel independen adalah sebesar 35\% sisanya sebesar $65 \%$ dijelaskan oleh variabilitas variabel-variabel lain diluar model penelitian. 


\section{Hasil Pengujian Hipotesis}

Tabel 4.2

Hasil pengujian hipotesis

\begin{tabular}{|c|c|c|c|}
\hline \multicolumn{5}{|c|}{ Hasil Pengujian Hipotesis } \\
\hline \multicolumn{2}{|c|}{ Pengujian Simultan } & \multicolumn{2}{c|}{ Pengujian Parsial } \\
\hline & Sig. & & B \\
\hline Step 1 Step &, 000 & Step 1 & IPM \\
\hline Block &, 000 & Educ &, 059 \\
\hline Model &, 000 & Earnings &, 057 \\
\hline & & Intern_c &,- 173 \\
\hline
\end{tabular}

\section{Pengujian Simultan}

Untuk mengetahui pengaruh variabel dependen terhadap variabel independen secara bersama-sama di dalam model, dapat menggunakan Uji G. Statistik G ini menyebar menurut sebaran khi kuadrat (X2). Uji G ini menunjukkan bahwa model logistik secara keseluruhan dapat menjelaskan atau memprediksi variabel independen terhadap variabel dependen, untuk pengujian secara simultan dapat dilihat pada tabel 4.2 diatas. Berdasarkan tabel 4.2 diperoleh nilai signifikansi model sebesar 0,000 dan nilai ini lebih kecil dari 0,05 , maka $\mathrm{H}_{0}$ ditolak sehingga dapat disimpulkan bahwa variabel indeks pembangunan manusia, tingkat pendidikan masyarakat, tingkat pendapatan maysarakat, dan sistem pengendalian intern secara bersama-sama berpengaruh terhadap opini audit laporan keuangan pemerintah daerah.

\section{Pengujian Parsial}

Berdasarkan hasil perhitungan dengan menggunakan program spss versi 23.0, hasil regresi dapat dilihat pada lampiran 5. Ringkasan hasil pengujian hipotesis dapat dilihat pada tabel 4.2. Pada variabel Indeks Pembangunan Manusia. Hasil penelitian menunjukkan bahwa koefesien regresi $\left(\beta_{1}\right)$ untuk variabel indeks pembangunan manusia $\left(\mathrm{X}_{1}\right)$. Koefesien regresinya bernilai 0,059 yang berarti $\beta_{1} \neq 0$. Hasil penelitian menolak hipotesis nol $\left(\mathrm{H}_{01}\right)$ dan tidak dapat menolak hipotesis pertama $\left(\mathrm{H}_{1}\right)$. Artinya indeks pembangunan manusia berpengaruh possitif terhadap opini audit laporan keuangan pemerintah daerah.

Pada vaeiabel tingkat pendidikan masyarakat Hasil penelitian untuk hipotesis kedua menunjukkan bahwa tingkat pendidikan masyarakat berpengaruh terhadap opini audit laporan keuangan pemerintah daerah pada kabupaten/kota di Aceh hal ini ditunjukkan dengan melihat nilai koefesien regresi $\left(\beta_{2}\right)$ untuk variabel tingkat pendidikan masyarakat. Koefesien regresi $\left(\beta_{2}\right)$ variabel tingkat pendidikan masyarakat sebesar 0,253 yang berarti bahwa $\beta_{2} \neq 0$. Hasil penelitian ini menolak hipotesis nol $\left(\mathrm{H}_{02}\right)$ dan tidak dapat menolak hipotesis kedua $\left(\mathrm{H}_{2}\right)$. Artinya tingkat pendidikan masyarakat berpengaruh terhadap opini audit laporan keuangan pemerintah daerah.

Pada variabel Tingkat Pendapatan Masyarakat. Hasil penelitian untuk hipotesis ketiga menunjukkan bahwa tingkat pendapatan masyarakat berpengaruh terhadap opini audit laporan keuangan pemerintah daerah pada kabupaten/kota di Aceh, hal ini ditunjukkan dengan melihat nilai koefesien regresi $\left(\beta_{3}\right)$ untuk variabel tingkat pendapatan masyarakat. Koefesien regresi $\left(\beta_{3}\right)$ variabel tingkat pendapatan masyarakat sebesar 0,057 yang berati bahwa $\beta_{3} \neq 0$. Hasil penelitian ini menolak hipotesis nol $\left(\mathrm{H}_{03}\right)$ dan tidak dapat menolak hipotesi ketiga $\left(\mathrm{H}_{3}\right)$. Artinya tingkat pendapatan masyarakat berpengaruh terhadap opini audit laporan keuangan pemerintah daerah.

Pada variabel sistem pengendalian intern. Hasil penelitian untuk hipotesis keempat menunjukkan bahwa sistem pengendalian intern berpengaruh negatif terhadap opini audit laporan keuangan pemerintah daerah pada kabupaten/kota di Provinsi Aceh, hal ini ditunjukkan dengan nilai koefesien regresi $\left(\beta_{4}\right)$ untuk variabel sistem pengendalian intern. Koefesien regresi $\left(\beta_{4}\right)$ variabel sistem pengendalian intern sebesar - 0,173 yang berarti bahwa $\beta_{4} \neq 0$. Hasil penelitian ini menolak hipotesis nol $\left(\mathrm{H}_{04}\right)$ dan tidak dapat menolak $\left(\mathrm{H}_{4}\right)$. Artinya sistem pengendalian intern berpengaruh negatif terhadap opini audit laporan keuangan pemerintah daerah pada kabupaten/kota di Aceh. 


\section{Pembahasan}

Pengaruh Indeks Pembangunan Manusia terhadap Opini Audit Laporan Keuangan Pemerintah Daerah.

Hasil pengujian menunjukkan bahwa indeks pembangunan manusia berpengaruh terhadap opini audit laporan keuangan pemerintah daerah. Sebagai ukuran dari kualitas hidup sendiri IPM dibangun melalui pendekatan tiga dimensi dasar dan dimensi tersebut berupa umur panjang dan sehat, pengetahuan dan kehidupan yang layak (BPS Aceh, 2016).

Hal ini terbukti dari beberapa kabupaten/kota yang memiliki indeks pembangunan manusia yang baik akan cenderung medapatkan opini yang lebih baik dan juga peningkatan indeks pembangunan manusia untuk beberapa tahun terakhir cenderung diikuti peningkatan/perbaikan opini audit laporan keuangan pemerintah daerah pada kabupaten/kota di Aceh. Penelitian ini sejelan dengan penelitian yang dilakukan oleh Adzani \& Martani (2014) yang menemukan indeks pembangunan manusia berpengaruh positif signifikan terhadap opini audit laporan keuangan pemerintah daerah. Penelitian yang dilakukan Justus (2016), menunjukkan bahwa adanya hubungan yang positif dan signifikan antara indeks pembangunan manusia dan tata kelola pemerintahan yang baik.

\section{Pengaruh Tingkat Pendidikan Masyarakat terhadap Opini Audit Laporan Keuangan Pemerintah Daerah.}

Hasil pengujian hipotesis sebelumnya menunjukkan bahwa tingkat pendidikan masyarakat berpengaruh terhadap opini audit laporan keuangan pemerintah daerah. Artinya bahwa semakin baik pengetahuan masyarakat maka semakin baik juga pengawasan terhadap pemerintahan mereka sehingga terciptanya good governance. Penjelasan tersebut sesuai dengan beberapa penelitian sebeluamnya dimana Menurut Knack (2002), warga yang berpendidikan yang lebih baik mungkin lebih efektif dalam menuntut pemerintahan yang lebih efisien dan juga bisa menyediakan angkatan kerja yang lebih baik ketika pemerintah membutuhkan tenaga kerja yang handal. Penelitian yang dilakukan kadagidze (2015) menunjukkan bahwa pendidikan merupakan bagian dari transformasi masyarakat madani dimana warga negara yang memiliki latar beakang akademis berpartisipasi aktif dalam urusan publik. Kemudian penelitian yang dilakukan Adzani dan Martani (2014) menemukan bahwa tingkat pendidikan masyarkat berpengaruh terhadap opini audit laporan keuangan pemerintah. Ini artinya bahwa ketika pengetahuan masyarakat meningkat maka keterlibatan mereka dalam pemerintahan juga akan semakin baik karena masyarakat itu sendiri merupakan stakeholders dalam pemerintahan.

\section{Pengaruh Tingkat Pendapatan Masyarakat Terhadap Opini Audit Laporan Keuangan Pemerintah Daerah.}

Hasil pengujian hipotesis menunjukkan bahwa tingkat pendidikan masyarakat berpengaruh terhadap opini audit laporan keuangan pemerintah daerah pada kabupaten/kota di Aceh. Hal ini terbukti dari penelitian yang dilakukan oleh Serrano (2008), yang meneliti tentang faktor-faktor yang mempengaruhi pengungkapan keuangan pemerintah di internet yang menemukan bahwa tingkat pendapatan perkapita masyarakat berpengaruh terhadap pengungkapan informasi keuangan di internet, artinya bahwa ketika pendapatan masyarakat meningkat maka mereka tidak lagi memikirkan kebutuhan dasar mereka dan lebih peduli terhadap pemerintahan mereka sehingga pengawasan dari masyarakat akan meningkat dalam tata kelola keuangan pemerintah itu sendiri maupun pengawasan dalam penggunaan sumber daya keuangan agar lebih pada kepentingan masyarakat dan hal ini dibuktikan dengan peningkatan pendapatan perkapita masyarakat pada kabupaten/kota di Provinsi Aceh yang diikuti dengan perbaikan pada opini audit laporan keuangan pemerintah daerah.

Hasil ini sesuai dengan penelian yang dilakukan oleh Adzani dan Martani (2014) bahwa tingkat pendapatan masyarkaat berpengaruh terhadap opini audit laporan keuangan pemerintah.

\section{Pengaruh Sistem Pengendalian Intern Terhadap Opini Audit Laporan Keuangan Pemerintah Daerah.}

Hasil pengujian menunjukkan bahwa sistem pengendalian intern berpengaruh negatif terhadap opini audit laporan keuangan pemerintah daerah sistem pegendaian intern merupakan suatu elemen penting yang harus berjalan dengan baik karena semakin baik sistem pengendalian intern maka tujuan organisasi akan tercapai, seperti yang kita ketahui 
tujuan sistem pengendaliana intern adalah untuk memberikan keyakinan yang memadai bagi tercapainya efektivitas dan efisiensi dalam penyelenggaraan pemerintahan, keandalan pelaporan keuangan, pengamanan aset negara, dan ketaatan terhadap peraturan perundang-undangan, sehingga dapat kita simpulkan bahwa ketika sistem pengendalian intern berjalan dengan baik maka temuan atas pengendalian intern semakin sedikit dan kemungkinan untuk memperoleh opuni WTP akan semakin besar. Penelitian ini sejalan dengan penelitian yang dilakukan oleh Munawar, Nadirsyah, dan Abdullah (2016) yang menunjukkan bahwa temuan atas pengendalian intern berpengaruh negatif terhadap opini audit laporan keuangan pemerintah daerah. Kemudian penelitian yang dilakukan oleh Fatimah, Sari dan Rasuli (2014) menemukan bahwa sistem pengendalian intern berpengaruh terhadap penerimaan opini WTP, jadi jika temuan terhadap pengendalian intern meningkat maka perolehan opini audit akan semakin buruk atau akan sulit bagi pemerintah daerah untuk memperoleh opini wajar tanpa pengecualian.

\section{Kesimpulan, Implikasi, Keterbatasan, dan Saran \\ Kesimpulan}

Dari hasil pengujian hipotesis diperoleh kesimpulan sebagai berikut:

1. Indeks pembangunan manusia, tingkat pendidikan masyarakat, tingkat pendapatan masyarakat, dan sistem pengendalian intern secara bersama-sama berpengaruh terhadap opini audit laporan keuangan pemerintah daerah pada kabupaten/kota di Provinsi Aceh tahun 2010-2015.

2. Indeks pembangunan manusia berpengaruh terhadap opini audit laporan keuangan pemerintah daerah pada kabupaten/kota di Aceh tahun 20102015.

3. Tingkat pendidikan masyarakat berpengaruh terhadap opini audit laporan keuangan pemerintah daerah pada kabupaten/kota di Aceh tahun 20102015.

4. Tingkat pendapatan masyarakat berpengaruh terhadap opini audit laporan keuangan pemerintah daerah pada kabupaten/kota di Aceh tahun 20102015.
5. Sistem pengendalian intern berpengaruh terhadap opini audit laporan keuangan pemerintah daerah pada kabupaten/kota di Aceh tahun 2010-2015.

\section{Keterbatasan}

Penelitian ini memiliki keterbatasan yaitu, penelitian ini hanya menguji pengaruh peran masyarakat madani dan pengendalian intern terhadap opini audit laporan keuangan pemerintah daerah. Menurut hasil penelitian ini terdapat variabel lain diluar variabel yang telah diteliti yang mempengaruhi opini audit laporan keuangan pemerintah daerah.

\section{Saran}

Saran yang dapat diberikan dari penelitian ini dapat disimpulkan dalam beberapa hal yaitu:

1. Bagi penelitian selanjutnya untuk menggunakan variabel lain yang dapat mempengaruhi opini audit laporan keuangan pemeritah daerah, misalnya total aset, total belanja, dan belanja hibah.

2. Bagi pemerintah daerah, dikarenakan masih lemahnya sistem pengendalian intern yang dibuktikan dengan banyaknya temuan atas kelemahan sistem pengendalian intern sebaiknya terus berbenah dan memperbaiki sistem pengendalian intern agar lebih mudah untuk memperoleh opini WTP.

3. Untuk pengukuran peran masyarakat madani sebaiknya menggunakan data primer sehingga hasil yang didapat lebih mencerminkan keadaan yang sebenarnya bagaimana peran masyarakat madani terhadap opini audit laporan keuangan pemeritnah daerah dan juga bisa mendapatkan hasil yang lebih tepat dan akurat.

4. Peran masyarakat secara keseluruhan harus dimasukkan, artinya bahwa peran masyarakat itu bisa diukur dari bagaimana peran Lembaga Swadaya Masyarakat (LSM) dalam mengawasi tatakelola pemerintahan yang lebih baik, efektif, dan efisien dan juga peran masyarakat dalam tatakelola pemerintahan itu sendiri.

\section{Daftar Pustaka}

Adzani, A.H \& D. Martani. 2014. Pengaruh kesejahteraan masyarakat, faktor politik dan ketidakpatuhan regulasi terhadap opini audit laporan keuangan pemerintah daerah. 
Simposium Nasional Akuntansi 17 Mataram, Lombok, 1-23.

Akbar, B \& Achmad, D. 2015. Audit keuangan dan kesejahteraan rakyat studi pada kabupaten Badung, Tabana dan kota Denpasar Tahun 2015. Jurnal Tata Kelola \& Akuntabilitas Keuangan Negara.

Albert, A., Bawole, N. J., \& Domfeh, K. A. 2013. Improving Citizens ' Participation in Local Government Planning and Financial Management in Ghana: A Stakeholder Analysis of the Sefwi Wiawso Municipal Assembly. Department of Public Administration and Health Services Management, 3(2), 191-210. https://doi.org/10.5296/jpag.v3i2.3782.

Badan Pusat Statistik Provinsi Aceh. 2017. Indeks Pembangunan Manusia. Dapat diakses di: aceh.bps.go.id

Fatimah, D, Ria N.S. \& M. Rasuli. 2014. Pengaruh Sistem Pengendalian Intern, Kepatuhan Terhadap Peraturan Perundang-Undangan, Opini Audit Tahun Sebelumnya dan Umur Pemerintah Daerah terhadap Penerimaan Opini Wajar Tanpa Pengecualian pada Laporan Keuangan Pemerintah Daerah di Seluruh Indonesia. Jurnal Akuntansi, Vol. 3: 1 -15 .

Ghozali, Imam. 2013. Aplikasi Analisis Multivariate dengan Program SPSS. Yogyakarta: Badan Penerbit BPFE.

Hall, James A. \& Tommie Singleton. 2007. Information Technology Auditing and Assurance: Audit Teknologi Informasi dan Assurance. Jakarta : Salemba Empat.

Humas BPKP Palu. 2012. Peran BPKP dalam peningkatan opini WTP di Sulawesi Tengah. Berita Seputar BPKP dan Pengawasan. http://www.bpkp.go.id/berita/read/8463/0/Waw ancara-RRI-Palu-Peran BPKPdalampeningkatan-opini-WTP-di-Sulawesi-Tengah. bpkp. 05 Juni 2012.

Jensen, M. C and Meckling, W.H. 1976. Theory of the Firm : Managerial Behavior, Agency Costs and Ownership Structure . Journal of Financial Economics, Oktober, 1976, V. 3, No. 4, pp. 305360. Avalaible from: http://papers.ssrn.com.

Justus, B., \& Uma, A. D. 2016. Governance and Human Development in Gulu District: A Case
Study of Gulu Municipality. journal busines and management, 361-375.

Kadagidze, L. 2015. The Role Of Education In The Formation of Civil Society. European Scientific Journal, edition Vol.2, 100-111.

Kawedar, Warsito. 2009. Opini Audit dan Sistem Pengendalian Intern (Studi Kasus di Kabupaten PWJ yang Mengalami Penurunan Opini Audit). Dalam Jurnal Akuntansi dan Auditing, 6 (1): h: 1-9.

Knack, S. 2002. Social Capital and Quality and The Government: Evidence from State. American Journal of Political Science, Vol. 46, No. 4 (Oct., 2002), pp. 772-785.

Lurie, S. 2014. Higly Educated Countries Have Better Government. retrieved march 6, 2014, from https://www.theatlantic.com/education/archive /2014 /03/highly-educated-countries-havebetter-governments/284273/ .

Mahmud, Y. T dan A, Hudoyo. 2014. Faktor-Faktor Yang Mempengaruhi Pengungkapan Laporan Keuangan Di Internet oleh Pemerintah Daerah. Accounting Analysis Journal, 3(1): 361-369.

Munawar., Nadirsyah, \& Syukri, A. 2016. Pengaruh Jumlah Temuan Audit Atas Spi Dan Jumlah Temuan Audit Atas Kepatuhan Terhadap Opini Atas Laporan Keuangan Pemerintah Kabupaten/Kota Di Aceh. Jurnal Magister Akuntansi Pascasarjana Universitas Syiah Kuala. Volume 5, No. 2.

Ott, J. C. 2010. Government and Happiness in 130 Nations: Good Governance Fosters Higher Level and More Equality of Happiness. Soc Indic Res, 102:3-22 3-22. https://doi.org/10.1007/s11205-010-9719-z.

Ramachandran, H. 2002. Governance and People's Participation: Vision 2020. In India Vision 2020: Report Plus Background Papers, Planning Commission, Government of India, New Delhi.

Ratmono, I. W. 2015. Analisis Faktor-Faktor yang Mempengaruhi Ketersediaan dan Keteraksesan Internet Financial Reporting oleh Pemerintah Daerah. Journal of Accounting, Vol. 4. No 4: 2337-3806.

Republik Indonesia. Undang-Undang Nomor 15 Tahun 2004 tentang pemeriksaan pengelolaan dan tanggung jawab keuangan negara. 
Safitri dan Darsono. 2015. Pengaruh Sistem Pengendalian Internal Dan Temuan Kepatuhan Terhadap Opini Audit Pada Pemerintah Daerah. Journal of Accounting, Volume 5, Nomor 1, Tahun 2015, Halaman 1-12.

Sekaran, Uma dan Bougie, Roger. 2013. Research Methods for Business. United Kingdom: Jhon Wiley \& Sons Ltd.

Serrano-Cinca C, Rueda-Tomás M, Portillo-Tarragona P. 2008. Determinants of e-government extension. Online Information Review 33(3): 476-498.

Susanto, D. A. Yusuf, dan Y. Rachmawati. 2014. Pengaruh Good Governance Terhadap Kualitas Pemberian Layanan Publik. Jurnal Paradigma, Vol. 12, No. 02.

Ulum, A. S. 2011. Peran Pengukuran Kinerja Dalam Mendukung Good Governance Dalam Perspektif Agency Theory. Jurnal Dinamika Akuntansi, 3(1): 60-66.

UN Department of Economic and Social Affairs. 2013. "Citizen Engagement Practices by Supreme Audit Institutions: Compendium of Innovative Practices of Citizen Engagement by Supreme Audit Institutions for Public Accountability." New York: United Nations.

Wambui, A dan E. Kihonge. 2016. Effects Of Citizens' Levels Of Civic Awareness On Public Finance Management By The County Government Of Nyeri In Kenya. International Journal of Management and Commerce Innovations, Vol. 4, Issue 2, pp: (101106). 